\title{
THE TRANSFER OF GOVERNANCE FROM THE NATION STATE TO A CORPORATE GLOBAL ECONOMY
}

\author{
José G. Vargas-Hernández \\ Departamento de Mercadotecnia y Negocios Internacionales \\ Centro Universitario de Ciencias Económico Administrativas Universidad de Guadalajara
}

\section{Carlos A. Hinojosa Gómez \\ Universidad UNIVER}

\begin{abstract}
The purpose of this document is to analyze the emerging phenomenon of the transfer of state governance to global economic corporate governance. After determining the economic globalization processes driven by a corporate global economy, which affects the formation of glocalized business - intergovernmental networks, we discuss their outcome and impact. Finally we outline the main challenges facing governance driven by a corporate global economy.
\end{abstract}

Key words: global economy, globalization, governance, corporate economics.

\section{INTRODUCTION: THE GLOBAL ECONOMY AS AN EMERGING PHENOMENON}

One way to analyze the phenomenon of development in the era of globalization is through an approach involving interaction of the economic and the political. The political economy tries to connect economic analysis with practical policy to address problems related to development. It does so through the study of the social processes of institutional economic and political groups and their election decisions, regulatory power and influence over the allocation of resources.

The rhetoric surrounding the consolidation of the Cold War divided the world according to the degree of development of a country's economy. Countries that

Correspondence Address: Centro Universitario de Ciencias Económico Administrativas Universidad de Guadalajara. Periférico Norte 799 Edificio G- 306 Zapopan, Jalisco CP 45100 México. E-mail: josevargas@cucea.udg.mx; jgvh0811@yahoo.com 
were highly developed made up the first world, countries united through real socialism and not integrated into the global economy formed the second world, and eventually all other developed economies that were not named constituted the third world.

The globalizing market economy is not a homogeneous structure. It seeks the emergence of a decentralized regulation of markets coupled with a cosmopolitan and liberal democracy provided by transnational institutions. Cosmopolitan nations only work with a cosmopolitan democracy that moves towards globalization but also reaches down to social local organizations. This cosmopolitan democracy expands to regulate the efficiency of the global economy. The global economy, as it is today, is a complex and contradictory set of global markets, national development strategies and competitive corporate strategies (Borrus and Zysman, 1997). Here, it makes little sense to talk of national development if what is actually involved is the capitalist world economy.

Globalization processes are inextricably tied to competitiveness. In a global economy the pursuit of national competitiveness grows in line with the global system, putting this theoretical perspective in a privileged position to analyze current trends. However, because of its focus on historical evolution in the long run, the school has failed to capitalize on this advantage. It argues that evolution of this global system has led to the existing nations, including those in the Third World, and each has found its relative position in the international hierarchy.

The theory of the world capitalist system discusses "the formation and evolution of the capitalist mode of production as a system of economic social relations, political and cultural, born in the late Middle Ages in Europe that has evolved into a world system" according to Dos Santos (1998:130). His approach identifies the existence of a nucleus, a periphery and a semi periphery, in addition to distinguishing from among core economies, an economy that articulates the hegemonic system as a whole.

From the sociological perspectives, the existing world system school has come closer to predicting the general trend of events during the past quartercentury. The founder of the school, Immanuel Wallerstein, and his followers never tried to argue that the real capitalist world economy, which originated within the system of the European state in the sixteenth century and came to transcend the entire world, was the only unit of analysis. For them, newly industrializing countries are concerned with new formalization with their competitors as well as formal laws to gain a competitive advantage in their production in more regulated areas of the world's economy (Castells and Portes, 1989 ). Globality, convergence and competitiveness are cooperative principles of the new paradigm of economic globalization.

While the logic of a global economy prevails in the market, the logic of the state prevails in the political. Government has taken the overall dual logic of the 
nation state in a global economy. (Robinson, 2000). Stiglitz (2002) conceptualizes the current process of globalization as a comprehensive management system without a global government. Institutions like the World Trade Organization, IMF, the World Bank, and others make up a system of global management, but this is far from being a global government and it lacks a democratic mechanism of accountability.

\section{THE TRANSFER OF STATE GOVERNANCE TO ECONOMIC GOVERNANCE}

The global economy has altered economic structures and social policies at the level of the nation-state because the latter limits and impedes the processes of generation and capital accumulation. Now the existence of the structures of nation states are held hostage by the agents of global capitalism because this serves their transnational interests. In this context, the proposals that arise from neoliberal policies and principles recall the classic theory of economic liberalism in which a free market economy is taken as a hegemonic ideal that transforms the world economy in varying degrees according to the region and the country. This market economy requires institutions that facilitate trade.

The main condition imposed on the Nation State is the restructuring of the economies through neo-liberal so-called "structural adjustment". This aims to reduce government intervention in the economy by privatizing public sector enterprises and liberalizing international financial and trade flows, thereby gradually adjusting national economies into the global economy.

The structures of global governance are exogenous factors in the global economy because they provide sustenance to regulatory frameworks for large multilateral institutions, multinational corporations and national states, which has a direct impact on the regions and localities.

The governance of the global economy has a dual dimension. At one level large transnational corporations must work with the norms of multilateral organizations in global markets, and at another level intergovernmental structures interact with global value chains formed by clusters in iocal and regional locations.

\section{THE CORPORATE GLOBAL ECONOMY}

Globalization is a dark spot that has been spreading within the world economy and has begun to dominate the scene. This spot is the productive space won by the large corporation. The supremacy of the imperial state derives its strength from the power that the State's transnational corporations hold in exercising leadership in the global economy because they make investments, international fi- 
nancial transactions and global trade. By the rules of "leveling the playing field", foreign investment from rich countries requires poor countries to provide free access to their markets.

The 100 largest transnationals own assets worth more than 4.2 billion dollars, equivalent to $14.6 \%$ of the world's economy and $139.3 \%$ higher than the gross national product (GNP) of Latin American countries. These global corporations are operating in a global economy, producing standardized goods for domestic markets in internationalized economies. (Tedlow \&Abdelal, 2003).

Dieterich (2002) posits that the global economy is organized into a system of four rings: "The first ring or strategic center of this macro, which determines your direction and speed of evolution, is the five hundred largest corporations of the elite Overall, the group G-7.The second ring is the remaining thirty-seven thousand transnational corporations, which, in the overwhelming majority, also belong to the G-7." According to a Forbes survey of 500 major companies in the world, which followed criteria established by the Financial Times, the ownership and management of large transnational corporations is distributed as follows: the Americans have 48 percent, Europe 28 percent, and Japan 9 per percent. The value of American transnational corporations exceeds the combined value of the rest of the top 50 transnational corporations. 60 percent are American and 7 were ranked among the first places in 5 sectors. Furthermore, an American transnational corporation ranks first in 23 of 34 industry groups.

In the global economy, markets are transformed by corporations' efforts to listen to consumers on their preferences, not on facts as given to markets but as results in themselves. In global markets, the interactions between businesses and consumers, and culture and capitalism have transformed preferences to the point of homogenization, which causes some people to react positively or negatively in expressions of fundamentalism. For others, divergence and heterogeneity is a valid way to react to the mercerization of social life and financial and trade integration.

In a new era of homogenized demand in global markets, corporations require skills to move into markets of high quality standardized products. Despite the fact that consumption patterns may differ markedly between regions and countries, corporations can take advantage of economies of scale in production processes, distribution, and marketing to lower their prices.

\section{FORMATION OF GLOCALIZED CORPORATE- INTERGOVERNMENTAL NETWORK STRUCTURES}

Globalization is not only a process that transforms unilateral governance structures of production, distribution and the consumption level of national econo- 
mies in a global economy. In parallel, it also develops private global governance structures - such as global training system networks and value-added quasi hierarchies - to integrate local sites in the processes of production, distribution and consumption in world markets.

The infrastructure of the global economy is based on an interactive network, forming a system of several interrelated levels to respond to the growing challenges of a globalized economy. This network requires constant development potential with local and regional systems of cooperation in intra-regional locations. One element of this emerging global economy, according to North (1998), is the growing significance of cross-border transactions within the same firm or firms with cooperative agreements. The structures of global governance are exogenous factors in the global economy because they provide sustenance to regulatory frameworks for multilateral institutions, large multinational corporations, and national states, which has a direct impact on the regions and localities.

The emerging global economy is best described as entrepreneurial, underpinned and oriented by human resource development, and sensitive to constant environmental degradation. Unlike in classical economics, which considered tangible assets such as land valuable, the main assets of the emerging global economy are less tangible. The creation of business environments dates from just over a century. Participation in the emerging global economy requires innovation and risk taking business.

The globalization of industries can erase the boundaries between industries, producing a realignment of resources and processes. This happens through the increased mobility across national borders of company-specific resources and capabilities, especially intangible assets based on knowledge. In fact, one of the defining characteristics of globalization is the increased speed of transmission of knowledge. In a global economy, knowledge work - for both individuals and for nations - is the first resource for economic growth.

In a global economy, the development of communication technologies enabling instant information transfer and rapid transportation means that goods and services can be sent anywhere in the world in a short time. This has helped to facilitate the mobility of resources. Nevertheless, the dramatic reduction in long distance transportation and communication costs may be hindered by psychologi$\mathrm{cal}$ and cultural barriers between countries. New technologies flow to those who are able to acquire them, absorbing them into the global economy but widening the gap with those who can not acquire the new technologies.

In a bureaucracy, the goal is to codify valuable knowledge as fast as possible. In an economy based on physical objects, the organization achieves returns by deploying their knowledge to offer better products. The company's economic earnings create new knowledge, which it keeps for its own benefit in a pseudo monopoly. A dynamic economy for innovation develops competitive advantages 
and improves its positioning in the global economy. This innovation system is achieved through intraregional interaction among local businesses organized in clusters, which fosters learning. Regional economic geography began with an analysis of industrial districts in Italy (Becattini, 1990) at the end of the nineties and continued with studies of global cities as nodes of the global economy (Sassen, 2000) and city regions (Scott, 2001).

Economic cycles are shorter now than before, and the global economic crisis is now converging, with events beyond the control of global institutions. Producers, distributors and consumers converge under a new international division of labor where it is essential for intellectual property or knowledge to permeate the shared networks. This is the basis of human capital formation. Cooperative competitiveness is now the economic catalyst whose effects trigger growth based on the consumption of a variety of goods and services

The expansion processes of mythic globalization have contributed to the exaltation of a new individualism, which according to Giddens (1999), is associated with the demise of tradition and custom in our lives, a phenomenon related to the impact of globalization, and which is better understood than the influence of markets.

\section{ANALYSIS OF THE RESULTS AND EFFECTS OF THE GLOBAL ECONOMY}

The processes of globalization are yielding contrasting results between accelerated growth of the global economy and a growing polarization of social inequality. The model of the global economy - as understood and practised by the multilateral agencies such as the International Monetary Fund and World Bank among others - does not necessarily promote democratic development, or conditions of fairness and justice for the companies because the model is imposed, not proposed and accepted.

Ireland and Hitt (1999) claim that indications of the incredible breadth and depth of the effects of the global economy lead them to predict that nation states will lose their sovereignty in the twenty-first century.

The current globalization processes are dominated by the neoliberalism of the decalogue of the Washington Consensus, which generates inequality in trade competition and rapid acceleration of knowledge and technological development. Signs of the exhaustion of neoliberalism are visible in the regional financial crises that began in 1994 and the chaos caused by the dynamics of the new economy that was attributed to the Mexican crisis. The global economy entered into crisis in 2001.

A global economy centered in the United States is unsustainable due to the deep asymmetries and imbalances that exist among countries in the world. De- 
spite the hegemony of the capitalist system, which has continued to grow in the last two decades, the global economy is in continuous deflation. This endangers large investments and imperial U.S. hegemonic interests. Capitalists, already in tension and confrontation for a locus of power, are under pressure to maintain a leading edge that allows them to accelerate capital accumulation.

Perhaps the concept of hegemony in the world economy described in terms of centre, periphery and semi periphery is inappropriate to explain the dynamism of the rule with an emphasis on mastery by force. The U.S. imperial strategy to reverse the trend of the decline of hegemonic capitalism has caused more instability in the global economy, and thus, has led to some geopolitical arrangements that portend the imminent collapse of the imperial hegemony of capitalism. On the other hand, among these regimes there is a trend of growing discontent in the working classes, who have received few benefits. There is also discontent among critics from the right-wing regimes and their allies in the armed forces, who fear that even the limited democracy taking place in Latin America has gone too far.

The levels of disparity in growth rates and income distribution are growing. There is a serious concern to civilize and humanize the global economy. This concern is expressed by the same multinational agencies who falsely suggest the need for further liberalization processes by consolidating the so-called first-generation reforms and promoting second-generation reforms aimed at the strengthening of the institutions, the formulation and implementation of active social policies and the creation of social safety networks. If a globalized world economy is defined in terms of aims other than the maximization of wealth in the system, then efficiency based on profits must be considered inefficient with regard to that purpose.

\section{THE CHALLENGES OF THE GLOBAL ECONOMY}

The institutions of the global economy need political and social legitimacy within a democratic system to settle the problems of distributional effects, and harmful social and environmental causes in order to ensure the primacy of national and local governments as the pillars of global economic governance. This means nothing less than setting up an institution (Ordnungspolitik) for the global market to develop a global political order for a globalized economy.

Given the processes of globalization, one of the challenges facing governance is the formulation and implementation of economic policy. Jochimsen (2000: 36) defines the course of the discussion thus: The revolution in politics - the result of the triumph of markets - has been deep, leading national governments to embrace the global economy, but the agreements of the global economy can not be seen as just a group of bureaucrats and trade negotiators who are removed from the interests of the majority of the population. The common goal (...) should aim to create 
a global market economy that is viable in its social, economic and environmental consequences and in which players can compete effectively in clean and free markets through trade, capital, technologies, intellectual property, and currency.

In fact, the existing models of national development are dysfunctional given the new challenges posed by economic globalization processes, which are transforming the various economic, political, social and cultural aims. In contrast with predictions that emerged from the theory of dependence, which argued that dependent countries must gain, at least partially, some independence from the world economy, the priority for less developed countries is their integration into productive chains and global financial circles to avoid economic and political marginalization.

The biggest challenge facing the institutions in international governance is to reverse the trends of growing inequality that characterize the current processes of economic globalization, inequality both between different countries and within them.

According to Weaver and Rockman (1993), for countries that have recently become democratic, the responses to the challenges posed by economic development and political integration and social advancement of their peoples will significantly depend on the institutional design option. The Nation-state, organizations and administrators are players who must respond to the challenges facing existing institutions. The new power asymmetries are a key challenge for the new organizational forms.

Coordinated and coherent action in the international realm is required to ensure that the global economy is managed in everybody's interest. Coherence between international actions - national as well as local - ensures certain benefits for developing countries through their integration into the global economy. Reforms to national governments have to be accompanied by reforms in local governments and in relevant international institutions to substantiate a more coherent international regulation.

The highly speculative activities of the financial sectors that promote the global economy require regulatory functions of the State to ensure that the volatility of emerging capital markets do not harm their investments as well as to ensure financial market stability in order to achieve the maximum return on utility investment despite financial crises. The global economy faces problems associated with the regulation of financial markets, yet it is not possible to stop the project of a democratic and equitable world order in erratic world markets.

The challenge to integrate social policy into development goals requires identifying and introducing systems and processes for representative governments and citizens to make choices, resolve differences and account for decisions. It constitutes a challenge to establish policies that will lead to the provision of services to ensure equitable and quality access, according to minimum standards based on 
the needs and demands of users. Social policy must seek practices and innovations that will strengthen the capabilities of users to articulate and negotiate their demands, improve access to social services and monitor results.

Faced with the gradual decline in the number of contemporary welfare state societies, one of the main challenges is the empowerment of social and community organizations so that they can play an active role in their development processes. The biggest challenge facing civil society is the development of the powers to administer the society's own specific regulation of rights and obligations. In addition, neo-liberal market reforms are another factor that guides the reforms of the traditional Welfare State, which is an element within the national project. It is therefore, one of the main challenges facing the international political order.

To face the diversity of the socio-cultural challenges of a globalized economy, it is necessary to develop skills to manage this diversity to handle uncertainty and identity. The operation of the uncertainty can be anything from an integrated approach to a coordination standpoint, although both approaches have a common need for principles based on statutory criteria to avoid conflict. Therefore, economic and cultural differences are representative of major global cities. People increasingly experience greater cultural differences due to glocalization, and fragmentation creates challenges of identity, insecurity, anxiety, and uncertainty.

Within the competitive challenges posed by global markets of the nationstates and organizations, forces of increasing complexity and intensity are being identified. Nation-states and organizations use this knowledge to adapt to change and develop processes to identify the characteristics of their global competitors, taking into account their associated competitive advantages. Both entities, as do the new institutions, need to be endowed with powers and abilities to coexist in turbulent environments.

Hitt, Keats and De Maria (1998) argue that companies moving into new markets have many opportunities but also many challenges to overcome. They show how there are increased incentives for innovation and improvement opportunities to gain returns on this innovation. However, international expansion activities complicate operations in various environments. To take advantage of opportunities through positioning regional economies, companies must learn effective ways to coordinate operations across many countries' borders. The region can continue to increase integration in the global capitalist economy in the same way under the continuing influence of neo-liberal ideology and civil moderate right-wing regimes.

The challenge remains the urgent need to develop new social technologies capable of incorporating the informal sectors of the economy so that they can benefit from economic globalization processes. This is in clear contradiction with the current hegemonic development model. The pace, magnitude and direction of change caused by globalization will continue to progress rapidly through tech- 
nology transfer. It will join societies and cultures, change community values, and widen the gap between the rich and the poor. But it will also create opportunities and challenges for companies and organizations. Managing the change of dynamic management (Dowbor, 2001) requires an ongoing process of adjustment of different segments of social reproduction. 


\section{References}

Becattini, G. (1990) 'The Marshallian Industrial District as a Socio-Economic Nation', in F. PYKE, G. BECATTINI, y W. SENGENBERGER, W., (eds), Industrial Districts and Inter-Firm Co-operation in Italy, Geneva, 1990, p. 37-51.

Borrus, M. And Zysman, J. (1997) "Globalization with borders: The rise of Wintelism as the future of global competition". Industry and innovation, 1997, 141-66.

Castells, Manuel and Alejandro Portes (1989). "World underneath: the origins, dynamics and effects of the informal economy," in A. Portes, M. Castells, and L.a. Benton (eds.), The informal economy: studies in advanced and less developed countries, pp 11-37. Baltimore: Johns Hopkins University Press.

Dieterich Steffan Heinz (2002b)" Necesidad de empresas transnacionales latinoamericanas" La Nación, september 3.

Dos Santos T. (1998). La teoría de la dependencia, un balance histórico. En López Segrera, F; Los retos de la globalización, Ensayos en homenaje a Tehotonio Dos Santos, Tomo I, UNESCO.

Dowbor, Ladislau (2001). "Descentralization and governance", http://www.ppbr.com/ld/govern. shtml

Hitt, Michael A., Keats Barbara W., and DeMarie Samuel M. (1998). "Navigating in the new competitive landscape: Building strategic flexibility and competitive advantage in the $21^{\text {st }}$ century", Academy of Management Executive, Vol. 12, No. 4.

Ireland, R. Duane and Hitt Michael A. (199). "Achieving and maintaining strategic competitiveness in the $21^{\text {st }}$ century: The role of strategic leadership", Academy of Management Executive, Vol. 13, No.1.

Jochimsen, R., (ed.) (2000) Globaler Wettbewerb und weltwirtschaftliche Ordnungspolitik, Bonn.

North, D. (1998). La teoría económica neoinstitucionalista y el desarrollo latinoamericano. Proyecto PNUD "Red para la Gobernabilidad y el Desarrolio en América Latina- Instituto Internacional de Gobernabilidad. Barcelona, España.

Robinson, William I. (2000). "La globalización capitalista y la transnacionalización del estado", Revista Globalización. 2000. http:/www.rcci.net/globalización/2000/fg138.htm

Sassen, S. (2000). Cities in a World Economy, Thousand Oaks, 2000.

Scott, A. (2001) Global City-Regions. Oxford, 2001.

Stiglitz, Joseph (2002). "El descontento con la globalización", La Jornada, January 19.

Tedlow Richard, S. y Abdelal, Rawi (2003). Theodore Levitt's "The globalization of markets":An evaluation after two decades. Paper \#03-082 Harvard Business School.

Weaver R. Kent y Rockman, A. (eds.) (1993). "Do institutions matter? Government capabilities in the United States and Abroad. The Brookings Institution, Washington, DC. 


\section{Resumo}

O propósito deste trabalho é a análise de um fenómeno emergente: a transferência da governabilidade do Estado/Nação para a uma economia global e corporativa. Para além de determinar o impacto que os processos da globalizaçăo económica têm numa economia global corporativa, nomeadamente através da influência que têm na formaçāo de negócios organizados em redes intergovernamentais, discutem-se os seus efeitos. Finalmente, são apresentados os principais desafios que uma economia global coloca em termos do governo das sociedades - corporate governance.

Palavras chave: Economia global, globalização, governo, economia das sociedades. 